Taxing electricity consumption in Spain. Evidence to design the Post-Kyoto World*

J.M. Cansino $^{\mathrm{a}^{*}}$, M.A. Cardenete ${ }^{\mathrm{b}}$, M. Ordóñez ${ }^{\mathrm{c}}$ and R. Román ${ }^{\mathrm{a}}$

${ }^{a}$ University of Seville (Spain), Universidad Autónoma de Chile (Chile)and Universidad

Científica del Sur, Lima, (Perú).

${ }^{b}$ Dept. of Economics, Loyola University Andalucía (Spain)

${ }^{c}$ University of Seville (Spain)

Corresponding author: J.M. Cansino

Postal Address:

University of Seville

Faculty of Business and Economics

Avda Ramón y Cajal, $\mathrm{n}^{\text {o o }}$

Postal code: 41.005

Tel.: $34-954557528$

Email-address: jmcansino@us.es

\footnotetext{
* José M. Cansino, Manuel Ordóñez and Rocío Román wish to acknowledge the funding provided by project SEJ-132, and would also like to acknowledge the support of the Roger Torné Foundation by way of the Department of Energy and Environmental Economics at the University of Seville. These coauthors also wish to acknowledge the following projects: ECO2014-56399-R Project of Spanish Ministry of Economy and Competitiveness and 1150025 Project from FONDECYT of Chile's Ministry of Education. M. Alejandro Cardenete wishes to acknowledge the following projects: SEJ20000-60, CICYT ECO201021706, CICIYT ECO2009-11857 and SGR 2009-578.
} 


\section{Taxing electricity consumption in Spain. Evidence to design the Post-Kyoto World}

\section{Introduction}

In February of 2014, a Group of Experts commissioned by the Government of Spain presented its final report with the measures that could inspire an in-depth tax reform (Spanish Department of Finance, 2014). This report included the use of taxes to contribute to the battle against Climate Change and to reduce others taxes such as Social Security payments.

The report was presented the year prior to the Climate Summit in Paris (COP21 in acronym), which debated the legal instrument that will substitute the Kyoto Protocol. No doubt, some of the debate will focus on the instruments that countries must use to reach the established objectives. For the critics about the emission trade schemes (ETS) as a useful tool, taxing carbon represents the most effective instrument for pricing carbon so the proposal made by the Spain's Committee of Experts should be studied indepth as its results could help design a better international agreement.

In any case, independently of the final agreement reached by United Nations Climate Change Conference in Paris (see text of agreement at UN, 2015)., as one of the European Union (EU) Members States, Spain's authorities have to face staunch commitments derived from what is known as the H2020 strategy, which is the more ambitious EU package to fight against global warning. It includes a specific target of $20 \%$ for energy efficiency improvement. In terms of energy efficiency, Spanish commitment for the named $\mathrm{H} 2020$ implies that there must be a cumulative reduction in energy consumption of 15,979 ktoe for 2014-2020 (EU, 2012; Spanish Industry Ministry, 2014). This target is directly linked with electrical utilities as major provider of energy in Spain. 
However and until now, taxes have not been a policy instrument included in Spain's recent programs to enhance energy efficiency (E4, 2003 and IDAE, 2011). This might very well be due to fears about its possible damage on economy competitiveness in particular on industries like electrical utility and automative. So, it is relevant to know and assess the economic impacts of tax measures oriented towards energy efficiency improvements before taking a policy decision.

When energy prices increase, for example as a consequence of a new tax, utilities and others companies may respond in different ways; 1) they could change their product mix toward less energy intensive products; 2) they could invest in new technology that is less energy intensive; 3) they could to switch their energy input for a relatively cheaper fuel; or 4) they could prefer to cut back production levels (Andersen et al., 2011).

The implementation of economic instruments like carbon taxes leading to the internalization of the $\mathrm{CO}_{2}$ externality and an increase in energy prices could be expected to encourage manufacturing firms and households to adopt energy-saving technologies and practices. If an effective energy efficiency policy is to be pursued, then economic instruments providing a price signal to reduce energy demand should be applied (Tarancón et al., 2010). When energy prices fail to reflect the real cost of energy, consumers, utilities and others companies under-invest in energy efficient-equipment.

In this paper, a tax reform is proposed based on the establishment of an environmental Pigouvian tax. An environmental tax, following the double dividend approach (Goulder, 1995), would not only produce an improvement in the environment through enhancing energy efficiency, but could also generate other positive economic impacts associated with tax recycling (Manresa \& Sancho, 2005; Sancho, 2010). Thus, the revenues generated by this tax might be used to reduce other existing taxes, such as 
social contributions (Cardenete \& Sancho, 2002; Cardenete, 2004 and Llop \& Manresa, 2004). This approach is according with the fiscal devaluation policy recommendation by institutions like Bank of Spain (2014), IMF (2014) or OECD (2011) among others.

Based on the recommendations presented by the Committee of Experts aforementioned, this article proposes an environmental tax levied on electricity consumption at the same level as the tax applied on the products consumed by the economic sectors. This tax would differ from Spain's current electricity consumption tax, the essential aim of which is to collect revenue. ${ }^{\mathrm{i}}$ It is actually inspired by the British Climate Change Levy (CCL), which strives to promote the reduction of GHG emissions and where the tax burden is offset by a reduction of social contributions.

Spain's energy sector is a high energy intensity one and responsible for most of the GHG emissions released into the atmosphere. The energy processing sector accounted for 77 percent of the total GHG emissions in Spain with the energy and transport industries producing the highest emission volumes. ${ }^{\text {ii }}$

The introduction of this new tax on energy into Spanish economy would presumably modify prices, electricity consumption, GHG emissions, tax revenues, private spending and other macroeconomic variables. To reach the right decision, it is essential to calculate its impacts on variables mentioned. This is the main contribution of this paper as it seeks to evaluate the impact that a tax reform based on the introduction of an environmental tax of the aforementioned characteristics would have mainly on electricity consumption and also on the rest of the rest of variables. The evaluation has been performed by considering two scenarios, without (Scenario 1) and with tax recycling between the new tax and employer-paid Social Security benefits or with tax using a price stability tool (Scenario 2). In Scenario 2, the tax reform is subject 
to two alternative restrictions. Firstly, a restriction would be imposed to ensure revenue neutrality (2-I). Secondly, another restriction would require that the tax reform guarantees price stability (2-II). Scenario 2-II does not properly imply a tax recycling process. It is focused on price stability as another political target which could be in the policy-maker agenda.

For this analysis, the Social Accounting Matrix (SAM) at purchase prices for Spain in 2006 (SAMESP06) developed by Cansino et al. (2012) has been used. This is the latest available SAM for the economy of Spain. The Matrix was constructed with the data from the origin and destination tables of the Input-Output (IO) framework and from accounting tables published by the National Statistics Institute (INE, 2009a and 2009b). The SAM serves as the database for a pricing model that includes the new tax.

The pricing model is an IO methodology model introduced by Leontief (1946) to study the relationship between wages, profits and prices in the U.S. economy of 1939. This methodology has been widely developed in relation to Spain's economy at both the domestic (Sancho, 1988; Roland-Holst \& Sancho, 1995; Llop, 2008 and more recently Tarancón et al., 2010). This model is an analytical method that is complementary to both the econometric approach (Buñuel, 2011; Labandeira \& Labeaga, 1999 and 2000) and the general equilibrium models developed in the field of environmental taxation by Bovenberg \& Goulder (1996), Böhringer (2002), Kumbaroğlu (2003) and O'Ryan et al. (2005), at the international level by Gómez \& Kverndokk (2002), André et al. (2005), Manresa \& Sancho (2005), De Miguel et al. (2009) and Labandeira et al. (2004), for the case of Spain ${ }^{\text {iii }}$.

Paper structures as follows. Following the introduction, the second section describes both the methodology and the tax on energy consumption. Section three 
shows the results obtained from the two scenarios. The fourth section presents the conclusions and implications for electrical utility industry.

\section{Methodology}

\subsection{The basic model}

The empirical basis upon which the model stands is found in each of the columns of the SAMESP06 at purchase prices that correspond to the 26 productive sectors considered. Each column represents the intermediate consumption of each of the activity areas or productive sectors while the other offers the primary factors used for the production of a single good. ${ }^{\text {iv }}$ The combination of various productive factors and intermediate consumptions, in fixed proportions and under the assumption of constant returns, results in each of the goods produced by each of the sectors indicated. This procedure isolates the price effects that are derived from the substitution effects, so that only partial information is available but lets us see the effect that the current structure has in the technology. This is a methodology for identifying price effects without any interference from the substitution effects, which require a different methodology, such as Computable General Equilibrium (CGE). A CGE cannot distinguish these two elements (prices and substitution effects because they are linked) while the linear model does, and that is the reason why we use it in this work.

In each column of the Primary Factors Matrix of the SAM at purchase prices, trade and transport margins are also shown, as well as the indirect taxes net of subsidies paid by the economic agents when demanding the goods and services required by companies that produce said goods/services (final demand). Hence, when combining the different components used to define the prices in the model, it is necessary to take into account the existence of two price types: one is the production price for each productive sector and the other is the purchase price or final price for each good produced. 
A series of intermediate consumptions reflected in the Intermediate Consumption Matrix of the SAMESP06 have been used to define a standard product. Along with them, a series of production, labor and capital factors have also been employed, to which imports must be added as another productive factor (Manresa, Polo \& Sancho, 1988). The labor factor is represented by the gross wages and salaries paid by businesses, and the capital factor by the Gross Operating Surplus and the Gross Mixed Income. These three production factors are included in the Primary Factors Matrix under the SAMESP06 headings Labor (27), Capital (28) and Imports (42). When calculating the production price, both indirect taxes net of subsidies on products (36) and production (37) and employer-paid Social Security contributions (34) must be added to these intermediate consumption and productive factors. From these data, the cost per unit of each good produced by each industry can be estimated (Cardenete \& Sancho, 2002). Following this scheme, the production price $^{\mathrm{v}}$ of the good produced by sector $j, p_{j}$, is contained in the following expression:

$$
p_{j}=\left(1+t_{j}\right)\left[\sum_{i=1}^{26} a_{i j} \cdot p_{j}+\left(1+s s_{j}\right) \cdot w \cdot l_{j}+r \cdot k_{j}+p_{m} \cdot m_{j}+i p r_{j}\right]
$$

where $t_{j}, i p r_{j}$ and $s s_{j}$ are the tax rates of net indirect taxes on products, production and employer-paid social contributions, respectively; $a_{i j}, l_{j}, k_{j}$ and $m_{j}$ represent, respectively, the technical coefficients of intermediate consumption, the labor factor, the capital factor and the imported goods; $w$ and $r$ are the unitary remuneration for labor (wage rate) and capital, respectively; $p_{m}$ is a price index for the imported goods. Thus, the last four summands on the right of expression (1) represent the contribution of each of the inputs required for the production of one good by each industry. Social contributions 
represent a portion of the remuneration for wage earners and indirect taxes represent a part of the production price.

The value of each parameter representing the technical coefficients was obtained from the SAMESP06. In the case of the technical coefficients referring to the intermediate consumption for each area of activity, it has been calculated from the following expression:

$$
a_{i j}=\frac{A_{i j}}{X I P_{j}}
$$

where $A_{i j}$ is the element taken from the Intermediate Consumption Matrix, i.e. the input consumption that sector $j$ makes from sector $i$, and $X I P_{j}$ is the total output of sector $j .{ }^{\mathrm{vi}}$ In the case of the productive factor, $l_{j}$, its calculation is based on the following expression:

$$
l_{j}=\frac{L_{j}+C S S_{j}}{X I P_{j}}
$$

where $L_{j}$ represents the salaries and wages of sector $j$ and $C S S_{j}$, the employer-paid social contributions. For productive factor $k_{j}$, the following expression has been used:

$$
k_{j}=\frac{K_{j}}{X I P_{j}}
$$

where $K_{j}$ is the Gross Operating Surplus of sector $j$. Finally, parameter $m_{j}$ is calculated as follows: 


$$
m_{j}=\frac{M_{j}}{X_{I P j}}
$$

where $M_{j}$ stands for the imports made by sector $j$.

The tax rates of net indirect taxes on intermediate products, production and employer-paid social contributions, and the technical coefficients have been obtained from the SAMESP06 through the following expressions:

$$
\begin{gathered}
t_{j}=\frac{I P_{j}}{X I P_{j}-I P_{j}} \\
i p r_{j}=\frac{I P R_{j}}{X I P_{j}} \\
S s_{j}=\frac{C S S_{j}}{C S S_{j}+L_{j}}
\end{gathered}
$$

where the numerator represents the revenue in each sector and the denominator, its tax base, which in the case of net indirect taxes is the total output minus the indirect tax that falls on the products paid by the sectors $\left(I P_{j}\right)$. The tax base of the taxes on production is the total output for each sector. In the case of employer-paid social contributions, the tax base is the sum of wages and salaries plus contributions. The tax rates obtained are not the nominal rates established by the existing regulations, but effective rates calculated from the SAM.

The purchase price is the result of adding trade and transport margins (39), together with the indirect taxes ${ }^{\mathrm{vii}}$ levied on finished products (38) and to the production price. The expression used to calculate the purchase price, $q_{j}$, is as follows: 


$$
q_{j}=\left(1+i d f_{j}\right) \cdot\left[p_{j}+m g_{j}\right]
$$

where $i d f_{j}$ is the net tax rate levied on finished products and applied as a percentage of the production price, $m g_{j}$ represents the trade and transport margins. Taxes are calculated as the quotient between the revenue and its tax base according to the SAMESP06, through the following expression:

$$
i d f_{j}=\frac{I D F_{j}}{D F_{j}-I D F_{j}}
$$

where $D F_{j}$ is the final demand. The parameter that represents the vector for trade and transport margins, $m g_{j}$, is obtained as follows:

$$
m g_{j}=\frac{M G_{j}}{D F_{j}}
$$

The production price, the purchase price and the wage rate are endogenously obtained within the model. This is not the case with the unitary remuneration of capital and the price of imported goods, which are considered exogenous in the model. With regard to the latter, since foreign prices are the outcome of the interaction of supply and demand in foreign markets, they fall outside the pricing model considered. For the remuneration of capital services, there is no benchmark index equivalent to what the Consumer Price Index represents as a reference for salaries. This is the reason why, following Cardenete \& Sancho (2002), this price is also considered exogenous in the model. 
Regarding the wage rate, it adjusts itself to the evolution of consumer prices through the Consumer Price Index ${ }^{\text {viii }}$ (CPI). Thus, to calculate the wage rate, which, in turn, behaves as a final price variation index, the following expression is used ${ }^{\mathrm{ix}}$ :

$$
w=\sum_{j=1}^{26} q_{j} \alpha_{j}
$$

where the wage rate, $w$, is a weighted average purchase price for the various goods produced by the productive sectors. $\alpha_{j}$ is the weight used, which represents the proportion of goods consumption $j$ in relation to total private consumption.

Taking into account the aforementioned references--where the data provided by the SAMESP06 are reproduced--the model sets the initial prices for both the products and the productive factors to unity. The model and the various simulations have been solved with the help of the GAMS ${ }^{\mathrm{x}}$ (General Algebraic Modeling System) software developed by Brook et al. (1988) for the World Bank.

\subsection{Electricity consumption tax and indirect revenue}

Following a scheme similar to that of Cansino et al. (2007), an electricity consumption tax (ECT) has been introduced into the above-described model. The effective tax rate of the ECT has been set, merely as a theoretical exercise, at 1 percent, without modifying the rest of the model. However, the results obtained will allow us to define rates to meet properly Spain's H2020 commitment in terms of energy efficiency. A $1 \%$ tax rate would be imposed on the supply of electricity ('taxable commodity') as fuels (that is lighting, heating, cooling and power) by business consumers. Electrical utilities become in a crucial piece of the fiscal mechanism. This tax would then be passed on to the final prices. The tax rate considered is charged at a specific rate per unit 
of electricity. This rate seeks to change business and household behavior in Spain to reduce electricity consumption with consequences for electrical utilities. Companies are considered taxpayers if they supply fossil fuels or electricity generated from fossil fuels, for commercial consumption. As such, they should register as suppliers. Utilities may be held liable and pay a penalty if they are required to register as taxpayers and fail to do so. This tax would be applicable to goods produced by the electricity sector (7) while other sectors in the model remain unchanged. This new tax is incorporated into the model at the same level as the net tax on products, as reflected on its calculation using the following expression:

$$
p_{j}=\left(1+t_{j}+e c t_{j}\right) \cdot\left[\sum_{i=1}^{26} a_{i j} \cdot p_{j}+\left(1+s s_{j}\right) \cdot w \cdot l_{j}+r \cdot k_{j}+p_{m} \cdot m_{j}+i p r_{j}\right]
$$

\subsection{The Private Spending Index}

Changes in purchase prices as a result of a tax modification give rise to variations in household purchasing power and spending level. The gain or loss of consumers' can be measured, following Cardenete \& Sancho (2002), through the socalled Private Spending Index (PSI), which calculates the variation in consumer expenditures, as required to purchase the original basket of goods and services at new prices. With this, $Y$ can be defined as the income used to purchase the original basket of goods and services and $Y^{\prime}$ as the income used to purchase the same basket of goods and services after the tax is introduced; the difference between the two will measure the variation in household expenditure between the initial and the final situation.

$$
P S I=Y-Y^{\prime}=\sum_{j=1}^{26} q_{j} \cdot C_{j}-\sum_{j=1}^{26} q_{j}^{\prime} \cdot C_{j}=\sum_{j=1}^{26}\left(q_{j}-q_{j}^{\prime}\right) \cdot C_{j}
$$


where $q_{j}$ and $q_{j}^{\prime}$ are, respectively, the initial and final purchase price of the basket of goods and services, $C_{j}$ is the basket of goods and services or consumption of the representative household. The PSI is the difference between $Y$ and $Y^{\prime}$; that is, the variation of consumer income after the tax has been introduced. A positive (negative) difference indicates that the final situation is better (worse) than the initial one, i.e. consumers will need a lower (higher) income to buy the same basket of goods and services, resulting in a higher (lower) level of household income. Although this measure includes neither the adaptation nor the modification of consumer habits in the face of the new prices, it helps to approach the improvement or worsening of private spending.

\section{Results}

The results obtained are associated with two reference scenarios. In the first, the tax reform does not entail the tax recycling of the new tax, the ECT. In the second scenario, the reform does include tax recycling or price stability as a target, which consists of counterbalancing the introduction of the ECT with a reduction of the employer-paid Social Security contributions. In the second scenario, the tax reform is subject to two types of alternative restrictions, one that requires the total tax revenue to remain constant (revenue neutrality) and the other that requires prices to remain constant (price stability) after the tax reform.

\subsection{Scenario 1}

The effective ECT tax rate has been set, merely as a theoretical exercise, at $1 \%$, without modifying the rest of the model. These results would allow a revised tax rate to be set to meet Spain's H2020 target. Table 1 shows the effects that the introduction of 
this tax would have on the price of the goods produced by the various areas of activity, as well as the average effect on the whole. The 2 nd column reflects the increase in production prices, while the 3 th shows the increase in purchase or consumption prices.

As expected, the introduction of the ECT gives rise to an increase in prices and this tax falls on the production prices which would later impact on acquisition prices.

However, the magnitude varies from one sector to another. The price of electricity shows the greatest increase. As was expected, Electrical utility industry receives the higher impact. In terms of purchase prices, the increase in these sectors is $3.58 \%$. Other goods experiencing an elevated increase, though small in relation to that of the aforementioned sectors, are those produced by the Retail and catering (22), Nonmarket services (26) Water (9) and Construction (21) sectors, among others. These are goods for which energy consumption has a relatively higher weight as an input, than it does for other products.

The reason behind this increase in the electricity sector can be found in their inputs demand. Electricity appears in the IO matrix as significant intermediate inputs for themselves (Alcántara et al., 2010). The fact that an important portion is selfconsumption is due to the structure of the sector. Within the IO framework, this activity area includes the production and distribution of electricity. In Spain, production, distribution and marketing are all activities that are undertaken by independent companies. Therefore, an important amount of the inputs are transactions among firms within the same area of activity. 
Table 1. Changes in prices and energy consumption

\begin{tabular}{|c|c|c|c|c|}
\hline \multirow{2}{*}{$\begin{array}{l}\text { Productive sector } \\
\text { Productive sector }\end{array}$} & \multicolumn{2}{|c|}{$\begin{array}{l}\text { Changes on the prices after } \\
\text { introduction of the ECT }(\%)\end{array}$} & \multicolumn{2}{|c|}{$\begin{array}{l}\text { Variation of primary energy } \\
\text { consumption (ktoe) }\end{array}$} \\
\hline & $\begin{array}{c}\text { Production } \\
\text { price }\end{array}$ & $\begin{array}{c}\text { Purchase } \\
\text { price }\end{array}$ & 2014 & 2014-2020 \\
\hline $\begin{array}{l}\text { 1. Agriculture, livestock and } \\
\text { forestry }\end{array}$ & 0.01 & 0.01 & -0.1 & -0.6 \\
\hline 2. Fisheries & 0.02 & 0.02 & 0.0 & 0.0 \\
\hline 3. Coal & 0.02 & 0.00 & 0.0 & -0.1 \\
\hline 4. Oil and natural gas & 0.00 & 0.00 & 0.0 & 0.0 \\
\hline 5. Non-energy extractive industries & 0.01 & 0.01 & 0.0 & -0.1 \\
\hline 6. Oil refineries & 0.00 & 0.00 & -2.5 & -17.4 \\
\hline 7. Electricity & 3.01 & 3.58 & $-1,468.4$ & $-10,278.9$ \\
\hline 8. Gas & 0.01 & 0.01 & 0.0 & 0.0 \\
\hline 9. Water & 0.05 & 0.05 & 0.0 & 0.0 \\
\hline 10. Food and stimulants & 0.03 & 0.02 & -0.3 & -1.8 \\
\hline 11. Textile and leather & 0.02 & 0.01 & 0.0 & -0.3 \\
\hline 12. Timber products & 0.03 & 0.02 & -0.6 & -4.0 \\
\hline 13. Chemical industry & 0.01 & 0.01 & -0.4 & -2.8 \\
\hline 14. Building materials & 0.04 & 0.03 & -1.0 & -6.7 \\
\hline 15. Metallurgy & 0.01 & 0.01 & -0.2 & -1.7 \\
\hline 16. Metal products & 0.04 & 0.04 & -0.1 & -0.9 \\
\hline 17. Machinery & 0.01 & 0.01 & 0.0 & -0.1 \\
\hline 18. Vehicles & 0.01 & 0.01 & 0.0 & -0.2 \\
\hline 19. Other transport elements & 0.02 & 0.02 & 0.0 & 0.0 \\
\hline 20. Other manufactured products & 0.03 & 0.03 & -0.1 & -0.7 \\
\hline 21. Construction & 0.05 & 0.05 & -0.1 & $\overline{-0.4}$ \\
\hline 22. Retail and catering & 0.04 & 0.13 & -0.3 & -2.2 \\
\hline 23. Transport and communications & 0.03 & 0.03 & -0.2 & -1.3 \\
\hline 24. Other services & 0.04 & 0.05 & 0.0 & -0.2 \\
\hline 25. Market services & 0.03 & 0.03 & -0.3 & -2.3 \\
\hline 26. Non-market services & 0.07 & 0.07 & -1.0 & -7.2 \\
\hline Overall variation & & 0.09 & $-1,475.7$ & $-10,330.1$ \\
\hline 2020 Target & & & & $64.6 \%$ \\
\hline
\end{tabular}

Source: Own elaboration based on SAMESP06

In terms of production prices, the increment is similar, reaching $3.01 \%$ for electricity. As for the remaining sectors, the price increase is most visible in the Nonmarket services sector (26) with a $0.07 \%$ rise, Construction (21) and Water (9), with increments of around $0.05 \%$. 
A rise in the price of electricity generates an increase of production prices for all sectors, which is higher as the input increases. This rise in production prices affects the increase of the final price for all goods and services. Furthermore, the increment of the final prices causes wage growth, which in turn-because wages are indexed to purchase prices through the CPI-becomes one of the factors contributing to the increase of prices. Nevertheless, the increase in the final price is mild, reaching only $0.09 \%$. Results in terms of price changes are in line with Buñuel (2011) who also found a little inflationary impact caused by a carbon tax leving various energy sectors. Labandeira \& Labeaga (1999) also carried out an IO excersise to assess some economic impacts of another carbon tax for the Spanish economy but not mainly foucused on sectoral prices changes.

The change in sectoral prices caused by the introduction of the ECT provoked a change in the pattern of household consumption as shown in Table 1. If the consumption is used as a proxy for overall output, it is possible to calculate the changes in energy consumption caused by the ECT. The sequence is as follows: The introduction of the ECT causes a change in the prices of both production and consumption of every sector. The latter modification causes a shift in the household consumption of the 26 sectors. This consumption's change implies a variation in the production sector and causes a change in the energy consumption. For the initial situation as well as for each of the scenarios considered, the consumption data are shown in Table 7. To calculate the change in the energy consumption data, the sectoral primary energy consumption data for 2014 (launch year for Spain's commitment for 2020) published by the Spanish Institute of Statistics are used. Relevant figures for Scenario I are contained in Table 1. . Column 4th in Table 1 shows the variation in primary energy consumption for the year in which ECT is applied (2014) and the accumulated variation for the 2014-2020 period (column 5th). It is understood that the annual variation for 2014 is maintained constant 
for all years of that period. Thus, by introducing ECT into this first scenario would allow us to reach $64.6 \%$ of the commitment for Spain for H2020. Impact on Electricity utility industry is clear and expected.

Table 2 shows the effects that the introduction of the ECT has on the collection of the various indirect taxes. The $0.28 \%$ increase in total revenue due to the introduction of ECT is not solely due to the new tax itself, but rather to an increment of the revenue from remaining indirect taxes, with the exception of the production tax, which remains unaffected. The reason for this cascade effect associated with the introduction of the ECT is that this measure originates an increase in prices, resulting in a higher tax base for the rest of the taxes. With regard to employer-paid social contributions, their tax base also increases because wages rise due to their being indexed to the CPI, as previously stated.

Table 2. Effects on the tax revenues and relative weight of the taxes

\begin{tabular}{|c|c|c|c|c|c|}
\hline \multirow[b]{2}{*}{ Type of tax } & \multicolumn{3}{|c|}{$\begin{array}{c}\text { Effects on the tax revenues of the } \\
\text { introduction of the ECT (millions of } \\
\text { Euros) }\end{array}$} & \multicolumn{2}{|c|}{$\begin{array}{l}\text { Relative weight of the taxes on } \\
\text { the total revenue }\end{array}$} \\
\hline & $\begin{array}{l}\text { Initial } \\
\text { situation }\end{array}$ & $\begin{array}{l}\text { With } \\
\text { ECT }\end{array}$ & Variation (\%) & Initial situation & With ECT \\
\hline $\begin{array}{l}\text { Net taxes on } \\
\text { products } \\
\text { (industries) }\end{array}$ & $22,164.6$ & $22,171.1$ & 0.03 & 10.38 & 10.35 \\
\hline $\begin{array}{l}\text { Net taxes on } \\
\text { production }\end{array}$ & $1,915.0$ & $1,915.0$ & 0.00 & 0.90 & 0.89 \\
\hline $\begin{array}{l}\text { Employer-paid } \\
\text { social } \\
\text { contributions }\end{array}$ & $104,148.0$ & $104,273.6$ & 0.09 & 48.78 & 48.68 \\
\hline $\begin{array}{l}\text { Net taxes on } \\
\text { finished } \\
\text { products }\end{array}$ & $85,293.4$ & $85,416.9$ & 0.14 & 39.95 & 39.89 \\
\hline ECT & 0.0 & 385.2 & - & 0.00 & 0.18 \\
\hline Total revenue & $213,521.0$ & $214,125.8$ & 0.28 & 100.00 & 100.00 \\
\hline
\end{tabular}

Source: Own elaboration based on SAMESP06 
The increase in revenue, higher in some taxes than others, together with new revenue from the ECT, slightly modifies the weight of taxes in relation to the total revenues. The results presented in Table 2 show that the introduction of the ECT reduces the relative weight of all taxes, more specifically 0.03 percentage points (pp) in the case of the net tax on intermediate products; $0.01 \mathrm{pp}$ in that of the net tax on production; $0.1 \mathrm{pp}$ for the employer-paid Social Security contributions, and $0.06 \mathrm{pp}$ for the tax on finished products. The relative weight of the ECT is thus $0.18 \%$ of the total.

\subsection{Scenario 2}

In this second scenario, the tax reform involves, in addition to the introduction of the ECT, a reduction of the employer-paid Social Security benefits. The reform is also subject to a first restriction of revenue neutrality and to a second restriction of price stability.

This second scenario draws inspiration from Cardenete \& Sancho (2002) and the British $\mathrm{CCL}^{\mathrm{xi}}$, where the introduction of the rate is compensated by a $0.3 \%$ reduction of the employer-paid social contributions. In the present model, the offset of employerpaid social contributions required to ensure that the tax reform is financially neutral, in terms of both revenue (scenario 2-I) and prices (scenario 2-II), has been calculated.

Table 3 shows the results regarding the tax rates that affect each of the 26 sectors. The 2nd column presents the effective rate of the initial employer-paid social contributions, that is, before the introduction of the ECT and the offset through their reduction. The 3 rd and 4th columns reflect the decrease in the effective rates of the contributions in order to satisfy the required restrictions: in the first case, maintaining revenue neutrality. 
Table 3. Social contributions and effects on final prices

\begin{tabular}{|c|c|c|c|c|c|}
\hline \multirow[b]{2}{*}{ Productive sector } & \multicolumn{3}{|c|}{$\begin{array}{l}\text { Employer-paid social contributions } \\
\text { simulated to reach the set targets }\end{array}$} & \multicolumn{2}{|c|}{$\begin{array}{l}\text { Effects on the final } \\
\text { prices of the } \\
\text { introduction of the } \\
\text { ECT and changes in } \\
\text { the effective rates of } \\
\text { employer-paid social } \\
\text { contributions }(\%)\end{array}$} \\
\hline & $\begin{array}{l}\text { Initial social } \\
\text { contributions }\end{array}$ & $(2-I)$ & (2-II) & (2-I) & (2-II) \\
\hline $\begin{array}{l}\text { 1. Agriculture, livestock and } \\
\text { forestry }\end{array}$ & 0.1254 & 0.1248 & 0.1245 & -0.0033 & -0.0111 \\
\hline 2. Fisheries & 0.1434 & 0.1427 & 0.1423 & -0.0061 & -0.0182 \\
\hline 3. Coal & 0.2825 & 0.2812 & 0.2805 & -0.0041 & -0.0085 \\
\hline 4. Oil and natural gas & 0.2041 & 0.2031 & 0.2026 & -0.0001 & -0.0003 \\
\hline $\begin{array}{l}\text { 5. Non-energy extractive } \\
\text { industries }\end{array}$ & 0.2388 & 0.2377 & 0.2371 & -0.0110 & -0.0240 \\
\hline 6. Oil refineries & 0.2801 & 0.2788 & 0.2780 & -0.0038 & -0.0079 \\
\hline 7. Electricity & 0.2595 & 0.2583 & 0.2576 & 3.5526 & 3.5343 \\
\hline 8. Gas & 0.2718 & 0.2706 & 0.2699 & -0.0105 & -0.0219 \\
\hline 9. Water & 0.2574 & 0.2562 & 0.2555 & -0.0499 & -0.1060 \\
\hline 10. Food and stimulants & 0.2337 & 0.2326 & 0.2320 & -0.0198 & -0.0436 \\
\hline 11. Textile and leather & 0.2229 & 0.2219 & 0.2213 & -0.0108 & -0.0244 \\
\hline 12. Timber products & 0.2262 & 0.2252 & 0.2246 & -0.0188 & -0.0420 \\
\hline 13. Chemical industry & 0.2387 & 0.2376 & 0.2370 & -0.0102 & -0.0222 \\
\hline 14. Building materials & 0.2390 & 0.2379 & 0.2372 & -0.0296 & -0.0645 \\
\hline 15. Metallurgy & 0.2522 & 0.2510 & 0.2503 & -0.0108 & -0.0231 \\
\hline 16. Metal products & 0.2263 & 0.2253 & 0.2247 & -0.0298 & -0.0666 \\
\hline 17. Machinery & 0.2333 & 0.2322 & 0.2316 & -0.0105 & -0.0232 \\
\hline 18. Vehicles & 0.2601 & 0.2589 & 0.2582 & -0.0105 & -0.0222 \\
\hline 19. Other transport elements & 0.2409 & 0.2398 & 0.2391 & -0.0168 & -0.0365 \\
\hline $\begin{array}{l}\text { 20. Other manufactured } \\
\text { products }\end{array}$ & 0.2245 & 0.2235 & 0.2229 & -0.0221 & -0.0495 \\
\hline 21. Construction & 0.2406 & 0.2395 & 0.2388 & -0.0454 & -0.0988 \\
\hline 22. Retail and catering & 0.2196 & 0.2185 & 0.2180 & -0.1018 & -0.2302 \\
\hline $\begin{array}{l}\text { 23. Transport and } \\
\text { communications }\end{array}$ & 0.2237 & 0.2227 & 0.2221 & -0.0248 & -0.0556 \\
\hline 24. Other services & 0.2238 & 0.2228 & 0.2222 & -0.0390 & -0.0875 \\
\hline 25. Market services & 0.1908 & 0.1899 & 0.1894 & -0.0171 & -0.0414 \\
\hline 26. Non-market services & 0.2290 & 0.2280 & 0.2274 & -0.0612 & -0.1358 \\
\hline Overall variation & 0.2238 & 0.2227 & 0.2222 & 0.0311 & 0.0000 \\
\hline
\end{tabular}

Source: Own elaboration based on SAMESP06

(2-I) Where the objective is to maintain the revenue.

(2-II) Where the objective is to maintain price stability. 
In both simulations, the calculated average rate of employer-paid Social Security benefits is lower than considered in the first scenario, which is the data recorded in the 2nd column (22.38\%). However, the reduction of the average rate is moderate. In the first case, the weighted average of the effective rate of the social contributions drops to $22.27 \%$, representing a reduction of only $0.49 \%$. In the second simulation, where reaching price stability is the objective, the reduction is $0.7 \%$.

The effects on revenue and prices are shown in Table 3 and 4. In the first case, where a $0.47 \%$ reduction of the average rate of the employer-paid Social Security contributions is required to maintain a constant revenue, there is a slight price increase of $0.031 \%$. In the second case, the average effective rate of the employer-paid Social Security contributions must be reduced by $0.7 \%$ to maintain stable prices, the total revenue experiences a $0.16 \%$ decrease.

Table 4. Effects on the tax revenues and the prices of a decrease in social contributions (millions of Euros)

\begin{tabular}{|c|c|c|c|}
\hline Type of tax & (1) & (2-I) & (2-II) \\
\hline $\begin{array}{l}\text { Net taxes on } \\
\text { products (industries) }\end{array}$ & $22,164.6$ & $22,153.9$ & $22,144.1$ \\
\hline $\begin{array}{l}\text { Net taxes on } \\
\text { production }\end{array}$ & $1,915.0$ & $1,915.0$ & $1,915.0$ \\
\hline $\begin{array}{l}\text { Employer-paid social } \\
\text { contributions }\end{array}$ & $104,148.0$ & $103,700.6$ & $103,396.6$ \\
\hline $\begin{array}{l}\text { Net taxes on finished } \\
\text { products }\end{array}$ & $85,293.4$ & $85,366.5$ & $85,337.9$ \\
\hline ECT & 0.0 & 385.1 & 385.0 \\
\hline Total revenue & $213,521.0$ & $213,521.0$ & $213,178.6$ \\
\hline Price index & 1.0000 & 1.00031 & 1.0000 \\
\hline $\begin{array}{l}\text { Scale factor of social } \\
\text { contributions }\end{array}$ & & 0.995 & 0.993 \\
\hline \multicolumn{4}{|c|}{$\begin{array}{l}\text { Source: Own elaboration based on SAMESP06 } \\
\text { (1) Initial situation. } \\
\text { (2-I) Simulation 1: Rate reduction of the employer-paid Social Security contributions } \\
\text { keeping the total revenue unchanged. } \\
\text { (2-II) Simulation 2: Rate reduction of the employer-paid Social Security contributions } \\
\text { keeping the prices unchanged. }\end{array}$} \\
\hline
\end{tabular}


If the revenue of the various taxes is analyzed, one observes that, in both simulations, net taxes on production remain constant and, as expected, both net taxes on products paid by the various areas of activity and social contributions decrease. However, in the case of net taxes on finished goods, the revenue slightly increases. The reason for this increment is the effect that the two simulations have on the final prices. In Table 3, the sixth and seventh columns respectively reflect the final prices in simulations 2-I and 2-II. Changes of the final prices modify, in turn, the tax base for the tax on finished goods. The tax base increases in the electricity sector but decreases in the other areas of activity; this translates into higher revenue in the first case and lower revenue in the rest. Nevertheless, the lower revenue cannot compensate the increase in the Electricity sector, causing the total revenue from this tax to be higher.

Similar to Table 1, and using the data from Table 7, Tables 5 shows the variation in energy consumption for each sector in scenarios 2-I and 2-II. Attaining the objective for $\mathrm{H} 2020$ is, in this case, $63.4 \%$ and $62.8 \%$, respectively. Once again, Electrical Utility industry receives directly the impact of the tax reform showing a decrease of $1,455.2$ ktoes for scenario 2-I and for the year 2014 and of 1,447.7 for scenario 2-II. 
Table 5. Variation of primary energy consumption (Ktoe). Scenarios 2-I and 2-II (revenue unchanged).

\begin{tabular}{lrrrr}
\hline & \multicolumn{2}{c}{ 2-I } & \multicolumn{2}{c}{ 2-II } \\
\hline Productive sector & (1) & \multicolumn{1}{c}{ (2) } & (1) & \multicolumn{1}{c}{ (2) } \\
\hline 1. Agriculture, livestock and forestry & 0.0 & 0.2 & 0.1 & 0.6 \\
2. Fisheries & 0.0 & 0.0 & 0.0 & 0.0 \\
3. Coal & 0.0 & 0.1 & 0.0 & 0.2 \\
4. Oil and natural gas & 0.0 & 0.0 & 0.0 & 0.0 \\
5. Non-energy extractive industries & 0.0 & 0.1 & 0.0 & 0.2 \\
6. Oil refineries & 2.8 & 19.8 & 5.8 & 40.9 \\
7. Electricity & $-1,455.2$ & $-10,186.3$ & $-1,447.7$ & $-10,133.8$ \\
8. Gas & 0.0 & 0.0 & 0.0 & 0.1 \\
9. Water & 0.0 & 0.0 & 0.0 & 0.0 \\
10. Food and stimulants & 0.2 & 1.6 & 0.5 & 3.4 \\
11. Textile and leather & 0.0 & 0.3 & 0.1 & 0.6 \\
12. Timber products & 0.5 & 3.4 & 1.1 & 7.6 \\
13. Chemical industry & 0.4 & 2.5 & 0.8 & 5.5 \\
14. Building materials & 0.9 & 6.2 & 1.9 & 13.4 \\
15. Metallurgy & 0.2 & 1.7 & 0.5 & 3.7 \\
16. Metal products & 0.1 & 0.7 & 0.2 & 1.6 \\
17. Machinery & 0.0 & 0.1 & 0.0 & 0.2 \\
18. Vehicles & 0.0 & 0.2 & 0.1 & 0.5 \\
19. Other transport elements & 0.0 & 0.0 & 0.0 & 0.1 \\
20. Other manufactured products & 0.1 & 0.6 & 0.2 & 1.4 \\
21. Construction & 0.1 & 0.4 & 0.1 & 0.8 \\
22. Retail and catering & 0.3 & 1.8 & 0.6 & 4.1 \\
23. Transport and communications & 0.2 & 1.1 & 0.4 & 2.5 \\
24. Other services & 0.0 & 0.2 & 0.1 & 0.4 \\
25. Market services & 0.2 & 1.5 & 0.5 & 3.7 \\
26. Non-market services & 0.9 & 6.3 & 2.0 & 13.9 \\
\hline Overall variation & $-1,448.2$ & $-10,137.5$ & $-1,432.6$ & $-10,028.5$ \\
\hline 2020 Target & & $63.4 \%$ & & $62.8 \%$ \\
\hline & & & & \\
Soure: Own ela & & & & \\
\hline
\end{tabular}

Source: Own elaboration based on SAMESP06

Table 6 shows how the rise in the final prices following the introduction of the ECT causes an increase of household spending that is associated with increased expenditure on the purchase of the original basket of goods and services. In Scenario 1, the increment of the final prices reduces the households' purchasing power that could be quantified in 554.3 million Euros. In the simulation for Scenario 2-I, the price reduction following the decrease of the average effective rates for the employer-paid social contributions softens the decline of the PSI until 59 million Euros. 
Table 6. Private Welfare Index (PWI) following the introduction of the ECT and its offset by a reduction of social contributions (millions of Euros)

\begin{tabular}{lc}
\hline & PWI \\
\hline $\begin{array}{l}\text { Initial situation } \\
\text { Introduction of the ECT }\end{array}$ & -554.0 \\
$\begin{array}{l}\text { Introduction of the ECT and offset by a reduction of } \\
\text { the contributions. Objective: to maintain the revenue }\end{array}$ & -59.0 \\
$\begin{array}{l}\text { Introduction of the ECT and offset by a reduction of } \\
\text { the contributions. Objective: to maintain the prices }\end{array}$ & 221.4 \\
\hline Source: Own elaboration based on SAMESP06
\end{tabular}

Source: Own elaboration based on SAMESP06

In the simulation for Scenario 2-II, the objective of maintaining price stability leads to a larger price reduction and, consequently to a reduction in the private spending that amounts to 221.4 million Euros. As seen in Table 7, the reduction in the consumption of goods produced by the Electricity sector (7) is offset by a gain in the consumption of other sectors, particularly Retail and Catering (22) and Market services (25). 
Table 7. Effect on consumption following the introduction of the ECT by sector (millions of Euros)

\begin{tabular}{llrrr}
\hline Productive sector & $\mathbf{( 1 )}$ & $\begin{array}{l}\text { (Scenari } \\
\text { (1) }\end{array}$ & (2-I $)$ & \multicolumn{1}{l}{ (2-II) } \\
\hline 1. Agriculture, livestock and forestry & $16,976.3$ & -1.8 & 0.6 & 1.9 \\
2. Fisheries & $5,603.6$ & -0.8 & 0.3 & 1.0 \\
3. Coal & 59.3 & 0.0 & 0.0 & 0.0 \\
4. Oil and natural gas & 63.1 & 0.0 & 0.0 & 0.0 \\
5. Non-energy extractive industries & 128.4 & 0.0 & 0.0 & 0.0 \\
6. Oil refineries & $21,504.0$ & -0.7 & 0.8 & 1.7 \\
7. Electricity & $7,859.3$ & -281.7 & -279.2 & -277.8 \\
8. Gas & $1,793.8$ & -0.2 & 0.2 & 0.4 \\
9. Water & $2,420.5$ & -1.2 & 1.2 & 2.6 \\
10. Food and stimulants & $74,606.0$ & -16.6 & 14.8 & 32.6 \\
11. Textile and leather & $34,873.2$ & -4.5 & 3.8 & 8.5 \\
12. Timber products & $3,293.4$ & -0.7 & 0.6 & 1.4 \\
13. Chemical industry & $13,740.4$ & -1.5 & 1.4 & 3.1 \\
14. Building materials & $1,140.5$ & -0.4 & 0.3 & 0.7 \\
15. Metallurgy & 177.6 & 0.0 & 0.0 & 0.0 \\
16. Metal products & $2,100.5$ & -0.7 & 0.6 & 1.4 \\
17. Machinery & $16,302.9$ & -1.9 & 1.7 & 3.8 \\
18. Vehicles & $22,688.4$ & -2.3 & 2.4 & 5.0 \\
19. Other transport elements & $2,504.7$ & -0.5 & 0.4 & 0.9 \\
20. Other manufactured products & $23,054.8$ & -6.1 & 5.1 & 11.4 \\
21. Construction & $9,530.1$ & -4.7 & 4.3 & 9.4 \\
22. Retail and catering & $127,989.9$ & -160.0 & 130.3 & 294.6 \\
23. Transport and communications & $34,567.0$ & -10.2 & 8.6 & 19.2 \\
24. Other services & $32,554.9$ & -15.2 & 12.7 & 28.5 \\
25. Market services & $124,616.1$ & -32.2 & 21.3 & 51.5 \\
26. Non-market services & $14,369.4$ & -10.2 & 8.8 & 19.5 \\
\hline Consumption/ & & & & \\
Private Welfare Index & $\mathbf{5 9 4 , 5 1 8 . 0}$ & $\mathbf{- 5 5 4 . 3}$ & $\mathbf{- 5 9 . 0}$ & $\mathbf{2 2 1 . 4}$ \\
\hline Sour & & & & \\
\hline
\end{tabular}

Source: Own elaboration based on SAMESP06

(1) Initial consumption.

(2-I) Changes in consumption following the introduction of the ECT and its offset with a decrease of social contributions. Objective: to maintain the revenue.

(2-II) Changes in consumption following the introduction of the ECT and its offset with a decrease of social contributions. Objective: to maintain price stability.

From previous results and from Table 7 , it is possible, by means of an iterative process, to calculate the effective tax rates that would allow each scenario to reach the exact target for Spain in 2020 in terms of energy efficiency. In scenario 1-that is with 
the introduction of ECT - it would be necessary to have a tax rate of $1.53 \%$ to reach the objective. In scenario 2-I, the ECT tax rate would be established at $1.56 \%$ and a decrease in social security payments of $0.73 \%$. If the objective is price stability (2-II), the ECT rate should be $1.58 \%$, with a reduction in social security payments of $1.15 \%$. The results show that the $1 \%$ rate was not far from being a tax reform that reaches $100 \%$ of Spain commitment for $\mathrm{H} 2020$.

Tables 8 to 11 offer the main results. Table 8 presents the results of the reduced consumption of primary energy by sectors, which would be attained upon introducing ECT into the scenarios contemplated. As could be expected Electricity Utility industry shows the higher values varying in a range from $-15,899.9$ ktoes to $-16,146.8$ Ktoes. For the same Industry impact on prices with H2020-rates is also higher than in the theoretical case; $5.54 \%(\min )$ and $5.63 \%(\max )$. 
Table 8. Effects on final prices and changes in energy consumption under full $\mathrm{H} 2020$

\begin{tabular}{|c|c|c|c|c|c|c|}
\hline \multirow[b]{2}{*}{ Productive sector } & \multicolumn{3}{|c|}{$\begin{array}{l}\text { Effects on the final prices of } \\
\text { the introduction of the ECT } \\
\text { and changes in the effective } \\
\text { rates of employer-paid } \\
\text { social contributions (\%) } \\
\text { (100\% H2020 commitment) }\end{array}$} & \multicolumn{3}{|c|}{$\begin{array}{l}\text { Variation of primary energy } \\
\text { consumption (Ktoe). }\end{array}$} \\
\hline & (1) & $(2-I)$ & (2-II) & (1) & (2-I) & (2-II) \\
\hline $\begin{array}{l}\text { 1. Agriculture, livestock and } \\
\text { forestry }\end{array}$ & 0.0163 & -0.0052 & -0.0177 & -0.9 & 0.3 & 0.9 \\
\hline 2. Fisheries & 0.0234 & -0.0097 & -0.0290 & 0.0 & 0.0 & 0.0 \\
\hline 3. Coal & 0.0056 & -0.0065 & -0.0136 & -0.1 & 0.2 & 0.3 \\
\hline 4. Oil and natural gas & 0.0002 & -0.0002 & -0.0004 & 0.0 & 0.0 & 0.0 \\
\hline $\begin{array}{l}\text { 5. Non-energy extractive } \\
\text { industries }\end{array}$ & 0.0186 & -0.0174 & -0.0383 & -0.1 & 0.1 & 0.3 \\
\hline 6. Oil refineries & 0.0052 & -0.0060 & -0.0125 & -26.9 & 31.2 & 65.1 \\
\hline 7. Electricity & 5.5453 & 5.5996 & 5.6314 & $-15,899.9$ & $-16,055.9$ & $-16,146.8$ \\
\hline 8. Gas & 0.0149 & -0.0166 & -0.0349 & 0.0 & 0.0 & 0.1 \\
\hline 9. Water & 0.0759 & -0.0787 & -0.1688 & 0.0 & 0.0 & 0.0 \\
\hline 10. Food and stimulants & 0.0344 & -0.0312 & -0.0695 & -2.7 & 2.5 & 5.5 \\
\hline 11. Textile and leather & 0.0202 & -0.0171 & -0.0388 & -0.5 & 0.4 & 0.9 \\
\hline 12. Timber products & 0.0343 & -0.0297 & -0.0670 & -6.2 & 5.4 & 12.1 \\
\hline 13. Chemical industry & 0.0172 & -0.0160 & -0.0354 & -4.3 & 4.0 & 8.8 \\
\hline 14. Building materials & 0.0498 & -0.0466 & -0.1028 & -10.4 & 9.7 & 21.4 \\
\hline 15. Metallurgy & 0.0169 & -0.0170 & -0.0368 & -2.7 & 2.7 & 5.9 \\
\hline 16. Metal products & 0.0543 & -0.0470 & -0.1061 & -1.3 & 1.2 & 2.6 \\
\hline 17. Machinery & 0.0184 & -0.0166 & -0.0370 & -0.2 & 0.2 & 0.4 \\
\hline 18. Vehicles & 0.0158 & -0.0166 & -0.0354 & -0.3 & 0.3 & 0.7 \\
\hline 19. Other transport elements & 0.0279 & -0.0264 & -0.0581 & -0.1 & 0.1 & 0.1 \\
\hline $\begin{array}{l}\text { 20. Other manufactured } \\
\text { products }\end{array}$ & 0.0407 & -0.0348 & -0.0788 & -1.1 & 1.0 & 2.2 \\
\hline 21. Construction & 0.0757 & -0.0715 & -0.1574 & -0.6 & 0.6 & 1.3 \\
\hline 22. Retail and catering & 0.1934 & -0.1604 & -0.3668 & -3.4 & 2.8 & 6.5 \\
\hline $\begin{array}{l}\text { 23. Transport and } \\
\text { communications }\end{array}$ & 0.0458 & -0.0391 & -0.0886 & -2.1 & 1.8 & 4.0 \\
\hline 24. Other services & 0.0721 & -0.0615 & -0.1394 & -0.3 & 0.3 & 0.6 \\
\hline 25. Market services & 0.0400 & -0.0269 & -0.0659 & -3.6 & 2.4 & 5.9 \\
\hline 26. Non-market services & 0.1094 & -0.0964 & -0.2164 & -11.2 & 9.9 & 22.1 \\
\hline Overall variation & 0.1331 & 0.0490 & 0.0000 & $-15,979.0$ & $-15,979.0$ & $-15,979.0$ \\
\hline 2020 Target & & & & $100 \%$ & $100 \%$ & $100 \%$ \\
\hline
\end{tabular}

Source: Own elaboration based on SAMESP06

(1) Introduction of the ECT.

(2-I) Where the objective is to maintain the revenue.

(2-II) Where the objective is to maintain price stability. 
For scenario 2-I is required a reduction of $0.7 \%$ of the average rate of the employed paid Social Security contributions to maintain a constant revenue (Table 9). In this case prices increase is of $0.05 \%$ (Table 8 ). For scenario 2-II is required a reduction of $1.16 \%$ of the average rate of the employed paid Social Security contributions. Impacts on different tax revenues (Table 10) are near to those for the case of $1 \%$ tax rate.

Table 9. Employer-paid social contributions simulated to reach the set targets (100\% H2020 commitment)

\begin{tabular}{|c|c|c|c|}
\hline Productive sector & $\begin{array}{l}\text { Initial social } \\
\text { contributions }\end{array}$ & $(2-\mathrm{I})$ & (2-II) \\
\hline 1. Agriculture, livestock and forestry & 0.1254 & 0.1245 & 0.1240 \\
\hline 2. Fisheries & 0.1434 & 0.1423 & 0.1417 \\
\hline 3. Coal & 0.2825 & 0.2804 & 0.2793 \\
\hline 4. Oil and natural gas & 0.2041 & 0.2026 & 0.2017 \\
\hline 5. Non-energy extractive industries & 0.2388 & 0.2371 & 0.2361 \\
\hline 6. Oil refineries & 0.2801 & 0.2780 & 0.2768 \\
\hline 7. Electricity & 0.2595 & 0.2576 & 0.2565 \\
\hline 8. Gas & 0.2718 & 0.2698 & 0.2687 \\
\hline 9. Water & 0.2574 & 0.2555 & 0.2544 \\
\hline 10. Food and stimulants & 0.2337 & 0.2320 & 0.2310 \\
\hline 11. Textile and leather & 0.2229 & 0.2213 & 0.2203 \\
\hline 12. Timber products & 0.2262 & 0.2246 & 0.2236 \\
\hline 13. Chemical industry & 0.2387 & 0.2370 & 0.2360 \\
\hline 14. Building materials & 0.2390 & 0.2372 & 0.2362 \\
\hline 15. Metallurgy & 0.2522 & 0.2503 & 0.2493 \\
\hline 16. Metal products & 0.2263 & 0.2247 & 0.2237 \\
\hline 17. Machinery & 0.2333 & 0.2316 & 0.2306 \\
\hline 18. Vehicles & 0.2601 & 0.2582 & 0.2571 \\
\hline 19. Other transport elements & 0.2409 & 0.2391 & 0.2381 \\
\hline 20. Other manufactured products & 0.2245 & 0.2229 & 0.2219 \\
\hline 21. Construction & 0.2406 & 0.2388 & 0.2378 \\
\hline 22. Retail and catering & 0.2196 & 0.2180 & 0.2170 \\
\hline 23. Transport and communications & 0.2237 & 0.2221 & 0.2212 \\
\hline 24. Other services & 0.2238 & 0.2222 & 0.2213 \\
\hline 25. Market services & 0.1908 & 0.1894 & 0.1886 \\
\hline 26. Non-market services & 0.2290 & 0.2274 & 0.2264 \\
\hline Weighted average & 0.2238 & 0.2222 & 0.2212 \\
\hline
\end{tabular}

Source: Own elaboration based on SAMESP06

(2-I) Effective rates of employer-paid social contributions required to keep the revenue constant. (2-II) Effective rates of employer-paid social contributions required to keep the prices constant. 
Table 10. Effects on the tax revenues and the prices of a decrease in social contributions (millions of Euros) (100\% H2020 commitment)

\begin{tabular}{|l|r|r|r|}
\hline Type of tax & (1) & (2-I) & (2-II) \\
\hline Net taxes on products (industries) & $22,174.6$ & $22,147.7$ & $22,132.0$ \\
\hline Net taxes on production & $1,915.0$ & $1,915.0$ & $1,915.0$ \\
\hline Employer-paid social contributions & $104,286.6$ & $103,442.8$ & $102,950.7$ \\
\hline Net taxes on finished products & $85,484.4$ & $85,408.6$ & $85,364.3$ \\
\hline ECT & 595.7 & 606.9 & 613.4 \\
\hline Total revenue & $\mathbf{2 1 4 , 4 5 6 . 4}$ & $\mathbf{2 1 4 , 4 5 6 . 4}$ & $\mathbf{2 1 2 , 9 7 5 . 4}$ \\
\hline Price index & 1.0013 & 1.0005 & 1.0000 \\
\hline Scale factor of social contributions & & 0.993 & 0.986 \\
\hline Source: Own
\end{tabular}

Source: Own elaboration based on SAMESP06

(1) Changes in consumption following the introduction of the ECT.

(2-I) Changes in consumption following the introduction of the ECT and its offset with a decrease of social contributions. Objective: to maintain the revenue.

(2-II) Changes in consumption following the introduction of the ECT and its offset with a decrease of social contributions. Objective: to maintain price stability.

Table 11 shows PSI changes. In Scenario 1, the increment of the final prices reduces the households' purchasing power that could be quantified in 857.4 million Euros. In the simulation for Scenario 2-I, the price reduction following the decrease of the average effective rates for the employer-paid social contributions softens the decline of the PSI until 93 million Euros. PSI raises up to 352.8 million in Scenario 2-II.

Table 11. Private Welfare Index (PWI) following the introduction of the ECT and its offset by a reduction of social contributions (millions of Euros) $(100 \% \mathrm{H} 2020$ commitment)

\begin{tabular}{lr}
\hline & PWI \\
\hline Initial situation & 0.0 \\
Introduction of the ECT & -857.4 \\
$\begin{array}{l}\text { Introduction of the ECT and offset by a reduction of } \\
\text { the contributions. Objective: to maintain the revenue }\end{array}$ & -93.0 \\
$\begin{array}{l}\text { Introduction of the ECT and offset by a reduction of } \\
\text { the contributions. Objective: to maintain the prices }\end{array}$ & 352.8 \\
\hline Source: Own elaboration based on SAMESP06 &
\end{tabular}

Finally, considering the changes in primary energy requirements, Table 12 contained total $\mathrm{CO}_{2}$ emissions avoided due to ECT. The original data came from 
Spanish National Statistics Institute (INE, 2015). However, data source used required to group some of 26 sectors considered in our analysis up to 20.

Table 12. $\mathrm{CO}_{2}$ emissions avoided up to 2020 (ktoe).

\begin{tabular}{|l|r|r|r|}
\hline Productive sector & \multicolumn{1}{|c|}{$(\mathbf{1})$} & \multicolumn{1}{c|}{$(\mathbf{2}-\mathbf{I})$} & \multicolumn{1}{c|}{ (2-II) } \\
\hline $\begin{array}{l}\text { Agriculture, livestock, forestry and } \\
\text { fisheries }\end{array}$ & -12 & 4 & 13 \\
\hline Energy extractive industries & 0 & 0 & 1 \\
\hline Non-energy extractive industries & -1 & 1 & 1 \\
\hline Oil refineries & -7 & 8 & 17 \\
\hline Electricity, gas and water & $-39,139$ & $-39,523$ & $-39,747$ \\
\hline Food and stimulants & -14 & 13 & 29 \\
\hline Textile and leather & -3 & 3 & 6 \\
\hline Timber products & -2 & 2 & 3 \\
\hline Chemical industry & -11 & 10 & 23 \\
\hline Building materials & -181 & 169 & 373 \\
\hline Metallurgy and metal products & -23 & 22 & 47 \\
\hline Machinery & -1 & 1 & 3 \\
\hline Transport elements & -2 & 2 & 5 \\
\hline Other manufactured products & -12 & 11 & 24 \\
\hline Construction & -29 & 28 & 61 \\
\hline Retail and catering & -93 & 77 & 176 \\
\hline Transport and communications & -117 & 99 & 225 \\
\hline Other services & -4 & 3 & 7 \\
\hline Market services & -11 & 7 & 18 \\
\hline Non-market services & -4 & 4 & 9 \\
\hline TOTAL VARIATION & $\mathbf{- 3 9 , 6 6 7}$ & $\mathbf{- 3 9 , 0 5 9}$ & $\mathbf{- 3 8 , 7 0 5}$ \\
\hline Source: Own
\end{tabular}

Source: Own elaboration based on SAMESP06

\section{Conclusions}

As an alternative of the Emissions Trade Schemes, carbon taxes might have an important opportunity in international agreements in post Kyoto Protocol World.

Electrical utilities are so important in the development of political measures against Climate Change due to the share of fossil fuels in the matrix. Many of these political measures are pricing carbon tools market oriented and several of marketoriented instruments are also linked with countries commitments in improving energy efficiency. This is the case of carbon taxes as a market oriented tool and this is also the case of Spain looking through energy efficiency commitments in H2020. 
In this work, a linear general equilibrium model has been applied to analyze the impact of a tax reform based on the introduction of a new tax on electricity consumption. The analysis considers two scenarios. These results allow regard the economic consequences due to the introduction of a tax. The results could be useful for international agreements in the Post-Kyoto World in order to reach national commitments.

The results obtained from a theoretical tax rate of $1 \%$ on Electricity consumption allow the ECT to be reviewed in an effort to reach Spain's objective for H2020. The fact that this Electrical Utility industry is a regulated one its sales and every details of invoices to clients make easier the tax reform develop. In scenario 1, with the introduction of ECT and to reach the objective, the tax rate would be $1.53 \%$. In scenario 2-I, and to attain revenue neutrality, an ECT tax rate would have to be established at $1.56 \%$ and a $0.73 \%$ decrease in social security payments. If the objective is stability of prices (2-II) the ECT rate should be $1.58 \%$, with a reduction in social security payments of $1.15 \%$.

When the H2020 energy efficiency objective is reached in full, the results obtained in this study allow us to conclude the following:

First, the introduction of an electricity consumption tax (ECT) without tax recycling has an inflationary impact, an important welfare loss (greater than the increase in revenue generated by the new tax) and an increase in the total tax revenue of $0.28 \%$.

Second, the introduction of the new tax (ECT) with tax recycling and tax neutrality requires a small reduction in employer-paid Social Security contributions and generates only a slight increase in consumer prices and a loss of household welfare less than the revenue generated by the new tax. 
Thirdly, the introduction of the new tax (ECT) with price stability leads to a decline in employer-paid Social Security contributions. This is higher than in the previous case, resulting in a $0.16 \%$ reduction in revenues and a significant increase of household welfare.

Last but not least, Electrical Utility sector act as a key driver to achieve the Spanish commitment by reducing largely its energy primary consumption. The $\mathrm{CO}_{2}$ emissions avoided by this sector are remarkable.

In summary, in the current context of economic and financial crisis, in which both price stability and tax neutrality seem essential requirements for all energy policy designs, we believe that the introduction of the new tax (ECT) with tax recycling and neutrality contribute to enhance Spanish energy efficiency at the cost of slightly increase inflation and moderately increase the private spending index. Although this paper considers an only tax rate for all of the utilities concerned, further analysis could enhances the tax design to a new one in with different tax rates which considered how clean/green is electricity for every utility considered as the key taxpayer.

It should be noted that the model used is a linear general equilibrium model. Although this kind of model is perfectly valid when analyzing the effect on prices and revenues, it is more limited than an applied general equilibrium model, which allows the establishment of a comprehensive and complex network of relationships between the different economic agents, as well as the consideration of a greater number of macroeconomic variables. We might be cautious with results obtained because of the limits of the analysis in the middle/long-terms. However, as an approximation to this network of interactions, the linear general equilibrium model provides enough insight into the effects that may result from a tax reform, and can be later expanded with the 
application of an applied general equilibrium model. These results are of interest to energy policy makers and designers fighting against climate change.

Finally, a pricing policy such as the ECT might be complemented with others instruments that include information for consumers and financial support for the purchase of energy-efficient appliances. Energy efficiency standards such as building energy codes and electric appliance would be also considered. Energy consumers may be informed about the negative impact of their energy demand on the global warming problem. 


\section{References}

Alcántara V., del Río P. \& Hernández (2010). Structural analysis of electricity consumption by productive sectors. The Spanish case, Energy. Volume 35 (5): 2088-2098.

André F.J., Cardenete M.A. \& Velázquez E. (2005). Performing an Environmental Tax Reform in a Regional Economy, Annals of Regional Science, 39 (2): 375-392.

Bank of Spain (2014). Informe anual 2013. Madrid: Bank of Spain.

Böhringer C. (2002). Environmental Tax Differentiation between Industries and Households: Implications for Efficiency and Employment. A Multi-Sector Intertemporal CGE Analysis for Germany, Centre for European Economic Research (ZEW), Discussion Paper No. 02-08, Mannheim.

Bovenberg L. \& Goulder L. (1996). Optimal Environmental Taxation in the Presence of Other Taxes: General-Equilibrium Analyses, The American Economic Review, 86 (4): 985-1000.

Brook A., Kendrick D. \& Meeraus A. (1988). GAMS, A User's Guide. The Scientific Press.

Buñuel M. (2011). El precio de la electricidad y la política de cambio climático: ¿qué papel puede jugar un impuesto sobre el carbono en España? /The Price of Electricity and Climate Change Policy: What Role May a Carbon Tax Play in Spain?, Estudios de Economía Aplicada, 29 (2): 1-18.

Cansino J.M., Cardenete M.A. \& Román R. (2007). Regional evaluation of a tax on the retail sales of certain fuels through a social accounting matrix, Applied Economics Letters, 14: 877-880. 
Cansino J.M., Cardenete M.A., Ordóñez M. \& Román R. (2012). Economic analysis of greenhouse gas emissions in the Spanish economy, Renewable \& Sustainable Energy Reviews, 16: 6032-6039.

Cardenete M. A. (2004). Evaluación de una Reducción de las Cuota Empresariales a la Seguridad Social a nivel Regional a través de un Modelo de Equilibrio General Aplicado: el Caso de Andalucía, Estudios de Economía Aplicada, 22: 1-10.

Cardenete M. A. \& Sancho F. (2002). Prices effects of indirect taxation in a regional economy, Journal of Applied Input-Output Analysis, 8: 1-13.

De Miguel F.J., Cardenete M.A. \& Pérez-Mayo J. (2009). Effects of the tax on retail sales of some fuels on a regional economy: a computable general equilibrium approach, Annals of Regional Science, 43: 781-806.

E4 (2003). Estrategia Española de Ahorro y Eficiencia Energética, 2004-2012 (Spanish strategy of saving and energy efficiency) approved by Spanish Government on 2003 november 28th.

EU 2012. DIRECTIVE 2012/27/EU OF THE EUROPEAN PARLIAMENT AND OF THE COUNCIL of 25 October 2012 on energy efficiency, amending Directives 2009/125/EC and 2010/30/EU and repealing Directives 2004/8/EC and 2006/32/EC.

Gómez A. \& Kverndokk S. (2002). Can carbon taxation reduce Spanish unemployment?, IX Encuentro de Economía Pública, Hacienda y Medioambiente, February 2002, Vigo.

Goulder L. (1995). Environmental Taxation and the Double Dividend: A Reader's Guide, International Tax and Public Finance, 2: 157-187.

IDEA (2011). Plan de Acción de Ahorro y Eficiencia Energética 2011 - 2020. http://idae.electura.es/publicacion/342/plan_ahorro_eficiencia_energ\%EF\%BF\%BD $\underline{\text { tica } 2011-}$ 
2020_2\%EF\%BF\%BD_plan_acci\%EF\%BF\%BDn_nacional_eficiencia_energ\%EF

\%BF\%BDtica_espa\%EF\%BF\%BDa. (last accesed 13/11/2014).

International Monetary Fund (IMF) (2014). Spain: 2014 Article IV Consultation

Concluding Statement of the Mission Madrid, May 27, 2014. http://www.imf.org/external/np/ms/2014/052714.htm

Instituto Nacional de Estadística (INE) (2009a). Marco Input-Output. Resultados 20002006, Madrid. www.ine.es.

--- INE (2009b). Cuentas económicas. Cuadros contables 2000-2008, Madrid. www.ine.es.

--- INE (2015). Air $\quad$ Emission Accounts. http://www.ine.es/dyngs/INEbase/es/operacion.htm?c=Estadistica_C\&cid=1254736176 941\&menu=resultados\&idp=1254735976603 (accessed December, 2015).

Kumbaroğlu G.S. (2003). Environmental taxation and economic effects: a computable general equilibrium analysis for Turkey, Journal of Policy Modeling, 25 (8): 795810.

Labandeira X. \& Labeaga J.M. (1999). Combining input-output analysis and microsimulation to assess the effects of carbon taxation on Spanish households, Fiscal Studies, 20: 305-320.

---- (2000). Efectos de un impuesto sobre las emisiones de $\mathrm{SO}_{2}$ del sector eléctrico, Revista de Economía Aplicada, 8 (22): 1-28.

Labandeira X., Labeaga J.M. \& Rodríguez M. (2004). Green Tax Reforms in Spain, European Environment, 14 (5): 290-299.

Leontief W. (1946). Wages, profit and prices, Quarterly Journal of Economics, 61(1): 26-39. www.qje.oxfordjournals.org. 
Llop M. (2008). Economic impact of alternative water policy scenarios in the Spanish production system: An input-output analysis, Ecological Economics, 68 (1, 2): 288294.

Llop M. \& Manresa A. (2004). The general equilibrium effects of social security contributions under alternative incidence assumptions, Applied Economics Letters, 11(13): 847-850.

Manresa A., Polo C. \& Sancho F. (1988). Una evaluación de los efectos del IVA mediante un modelo de producción y gasto de coeficientes fijos, Revista Española de Economía, 5: 45-64.

Manresa A. \& Sancho F. (2005). Implementing a double dividend: recycling ecotaxes towards lower labour taxes, Energy Policy, 33 (12): 1577-1585.

Ministerio de Medio Ambiente y Medio Rural y Marino (MMARM) (2011). Inventario de emisiones de gases de efecto invernadero de España. Edición 2011 (Serie 19902009), Madrid.

OECD (2011). OECD Perspectives: Spain Policies for a sustainable recovery. Organization for Economic Co-Operation and Development, Paris.

O’Ryan R., de Miguel C., Millar S. \& Munasnighe M. E. (2005). Computable General Equilibrium Model Analysis of Economy-wide Cross Effects of Social and Environmental Policies in Chile, Ecological Economics, 54 (4): 447-472.

Roland-Holst D.W. \& Sancho F. (1995). Modeling Prices in a SAM Structure, The Review of Economics and Statistics, 77 (2): 361-371.

Romero-Jordán D., Peñasco C. \& del Río, P. (2014). Analysing the determinants of household electricity demand in Spain. An econometric study, International Journal of Electrical Power \& Energy Systems, 63: 950-961. 
Sancho F. (1988). Una evaluación del peso de la imposición indirecta en los precios, Hacienda Pública Española, 113: 159-164.

--- (2010). Double dividend effectiveness of energy tax policies and the elasticity of substitution: A CGE appraisal, Energy Policy, 38 (6): 2927-2933.

Spanish Department of Finance (2014). http://www.minhap.gob.es/esES/Prensa/En\%20Portada/2014/Documents/Informe\%20expertos.pdf (last accesed May 11th, 2014)

Spanish Industry Ministry (2014). Planificación energética. Plan de desarrollo de la Red de Transporte de Energía Eléctrica. 2015-2020 http://www.minetur.gob.es/ energia/planificacion/Planificacionelectricidadygas/desarrollo2014-2020/ Documents/Documento\%20COMPLETO.pdf

Tarancón M.A., del Río P. \& Callejas F. (2010). Assessing the influence of manufacturing sectors on electricity demand. A cross-country input-output approach, Energy Policy, 38: 1900-1908.

UN (2015). Adoption of the Paris agreement. http://unfccc.int/resource/docs/2015/cop21/eng/109r01.pdf

\footnotetext{
* José M. Cansino, Manuel Ordóñez and Rocío Román wish to acknowledge the funding provided by project SEJ-132, and would also like to acknowledge the support of the Roger Torné Foundation by way of the Department of Energy and Environmental Economics at the University of Seville. These coauthors also wish to acknowledge the following projects: ECO2014-56399-R Project of Spanish Ministry of Economy and Competitiveness and 1150025 Project from FONDECYT of Chile's Ministry of Education. M. Alejandro Cardenete wishes to acknowledge the following projects: SEJ20000-60, CICYT ECO201021706, CICIYT ECO2009-11857 and SGR 2009-578.

i The electricity tax was implemented by Law 66/1997 of 30 December 1997 on Fiscal, Administrative and Social Order Measures, and had the basic objective of obtaining revenue to counterbalance the removal of an electricity billing surcharge that was meant to provide support to the coal industry.

ii Spain's Ministry of the Environment and Rural and Marine Affairs (MMARM, 2011).

iii The latter work integrates a micro-econometric model and a general equilibrium model.

iv In IO analysis, each area of activity considered produces a single good, employing the same production technology.
} 
$\mathrm{v}$ Each area of activity purchases the intermediate goods that it requires at their purchase prices, taxes included. However, the burden of indirect taxes does not fall on the producer but rather on the final consumer. Therefore, the price that must be taken into account is the production price.

vi The total output of sector $j$ does not correspond with the total number of uses or resources of the SAM, since it does not include the net indirect taxes (38) levied on the products making up the final demand or the trade and transport margins (39) on those same products.

vii Indirect taxes on products include the value added tax (VAT), taxes and duties on imports, excises, etc. The ideal would be to have these taxes expressed in a disaggregated form, especially in the case of VAT. However, the unavailability of disaggregated data of this tax by area of activity has made the consideration of all indirect taxes as a whole necessary.

viii The reason lies in that wage negotiations in the private sector and the establishment of the remuneration for public officials, the CPI is taken as the benchmark indicator. There are other possible assumptions, like using the total weight of salaries and wages in the sector in relation to the total wage bill, but the results obtained are very similar to those of CPI usage.

${ }^{\text {ix }}$ In Applied General Equilibrium (AGE) modeling, this assumption is very common (Manresa et al., 1988). The explanation is based on that households take their decision on base to real wages. This assumption is too suitable to include a labor market in the full non-linear AGE, taking account the relation between the real wages and the ration between real unemployment and the unemployment after the simulation.

$\mathrm{x}$ The solution software used by GAMS is MINOS.

xi The British CCL is intended to contribute to the reduction of greenhouse gas emissions. It is a tax on the consumption of products for lighting, heating and electricity of industry, commerce, agriculture and public administration sectors and for other services. The taxed products are electricity, gas, liquid hydrocarbons and coal. This rate is applied per nominal unit of power and, in the case of electricity, is $0.0043 £$ per kilowatt-hour. 